\title{
Imaging of Hidden Structures from the North Apuseni Mts, Romania, Using Narrow-Angle Seismic Reflection Data
}

\author{
Ionelia Panea \\ Faculty of Geology and Geophysics, University of Bucharest, Bucharest, Romania \\ Email:ipanea2@yahoo,com
}

How to cite this paper: Panea, I. (2020) Imaging of Hidden Structures from the North Apuseni Mts, Romania, Using Narrow-Angle Seismic Reflection Data. Open Journal of Geology, 10, 53-70.

https://doi.org/10.4236/ojg.2020.101003

Received: December 2, 2019

Accepted: January 4, 2020

Published: January 7, 2020

Copyright (๑) 2020 by author(s) and Scientific Research Publishing Inc. This work is licensed under the Creative Commons Attribution International License (CC BY 4.0).

http://creativecommons.org/licenses/by/4.0/

\section{(c) (i) Open Access}

\begin{abstract}
I present results of processing and structural interpretation of narrow-angle seismic reflection data recorded over an area of $30 \times 50 \mathrm{~km}$ located in the southern part of the North Apuseni Mts, Romania. The investigated area is characterized by complex subsurface geology and rough topography. The seismic measurements were performed along five linear profiles, P1-P5, using an active spread of 96 geophones for each shot point; geophone spacing was $25 \mathrm{~m}$. The length of each acquisition line is greater than $10 \mathrm{~km}$. The signal-to-noise ratio of these data varies along the lines and its variation is considered to be an effect of rough topography, complex subsurface geology and varying surface conditions encountered during seismic data acquisition. The data processing was performed using a standard processing flow but with different processing parameters from one data set to another. I obtained five depth-converted migrated seismic sections after data processing. The accuracy of the depth values depends on that of the stacking velocities obtained from the velocity analyses performed on the filtered seismic data. Borehole information is not available, the investigated area belonging to the areas investigated for hydrocarbons. Each seismic section shows a different structural image of the subsurface and provides useful information about the tectonic and stratigraphic evolution of the investigated area. I obtained various structural images of the subsurface after the interpretation of the depth-converted migrated seismic sections, from a simple one with undeformed and inclined reflectors to a complex one with folded and faulted reflectors, especially the older ones. I interpreted intrusive bodies piercing through the overlying sediments, which are in good agreement with the results of older geophysical studies.
\end{abstract}

\section{Keywords}

Structural Geology, Tectonics, Reflection Seismology, Reflection Seismic 
Imaging

\section{Introduction}

Accurate information about the subsurface geological structure is obtained after the integrated interpretation of the seismic and the borehole data recorded in studies performed for hydrocarbon exploration. The accuracy of the structural images of the subsurface depends on the complexity of the geological structure and the errors introduced during the seismic data acquisition and processing. Seismic reflection data can be recorded in two- or three-dimensional seismic surveys using short or long active geophone spreads for each shot point. Decades ago, on the Romanian territory, seismic reflection data were recorded using active spreads of 48 or 96 geophones for each shot point, the geophone spacing being $50 \mathrm{~m}$ or $25 \mathrm{~m}$. For structural interpretation, seismic data processing has been done using a standard processing flow [1].

Numerous hydrocarbon-bearing structures were identified, and exploited, in areas from the Romanian segment of the Eastern Pannonian Basin after the geological interpretation of the time seismic sections and the borehole data. Because of this, little information about seismic and borehole data and their interpretation was made available for external publications. Decades ago, a small set of seismic sections and borehole data provided by industry were used to explain the tectonic and stratigraphic evolution of the northern part of the Eastern Pannonian Basin [2]. For the Beius Basin, located in the southern part of the North Apuseni Mts, a structural contour map of the basement and an isopach map of the Neogene formations were built after the geological interpretation of the seismic sections provided by industry [3]; images with interpreted time seismic sections, the location and the distribution of the seismic lines are not shown in [3].

In this study, I analyze and process vintage seismic reflection data recorded in surveys performed for hydrocarbon exploration and made available by industry for research studies. The study area is located in the southern part of the North Apuseni Mts, which includes the Beius Basin; its size is about $30 \times 50 \mathrm{~km}$. The aim of the study is to image the complex geological structure of the subsurface using depth-converted migrated seismic sections obtained after the processing of narrow-angle seismic reflection data.

\section{Geological Description of the Study Area}

The investigated area is located in the southern part of the North Apuseni Mts (Figure 1). All five seismic lines, P1 - P5, are located in the area between the Padurea Craiului and Codru Moma Mts, Romania, mainly corresponding to the Beius Basin (Figure 2).

According to [4] and [5], the Apuseni Mts were formed in Cretaceous times as 


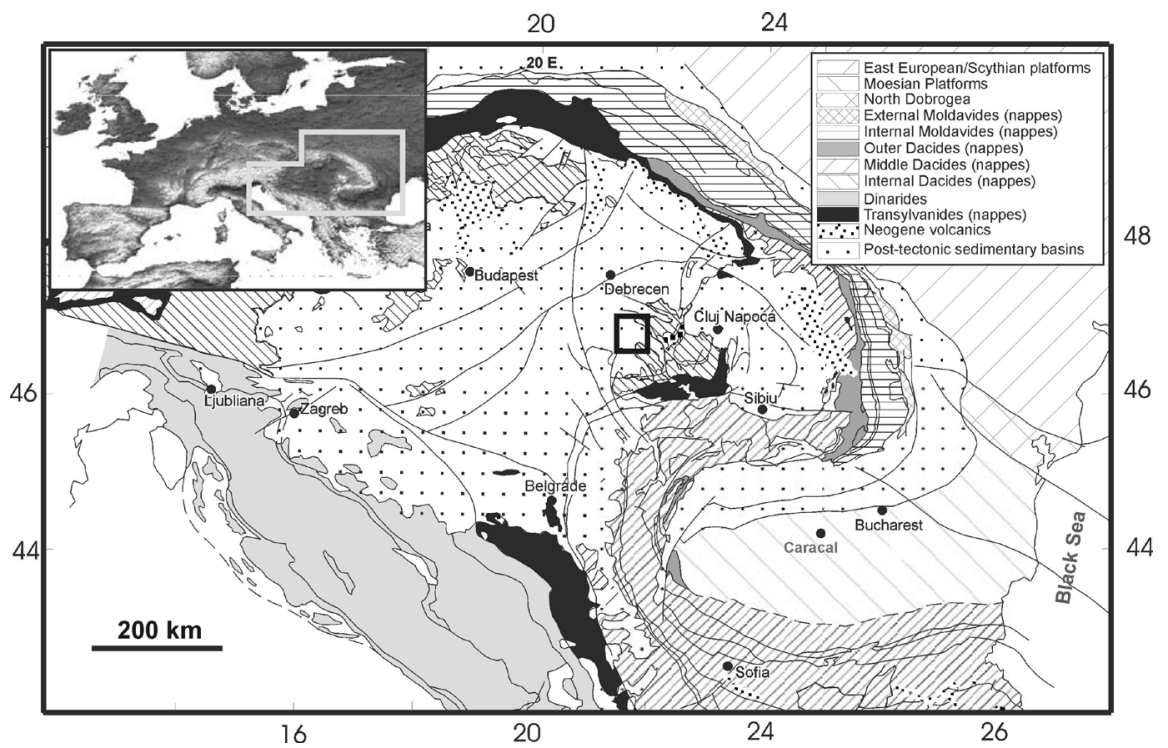

Figure 1. Tectonic map of the Carpathians/Dinarides/Pannonian Basin system in southeastern Europe (modified from [4]). Black rectangle-investigated area.

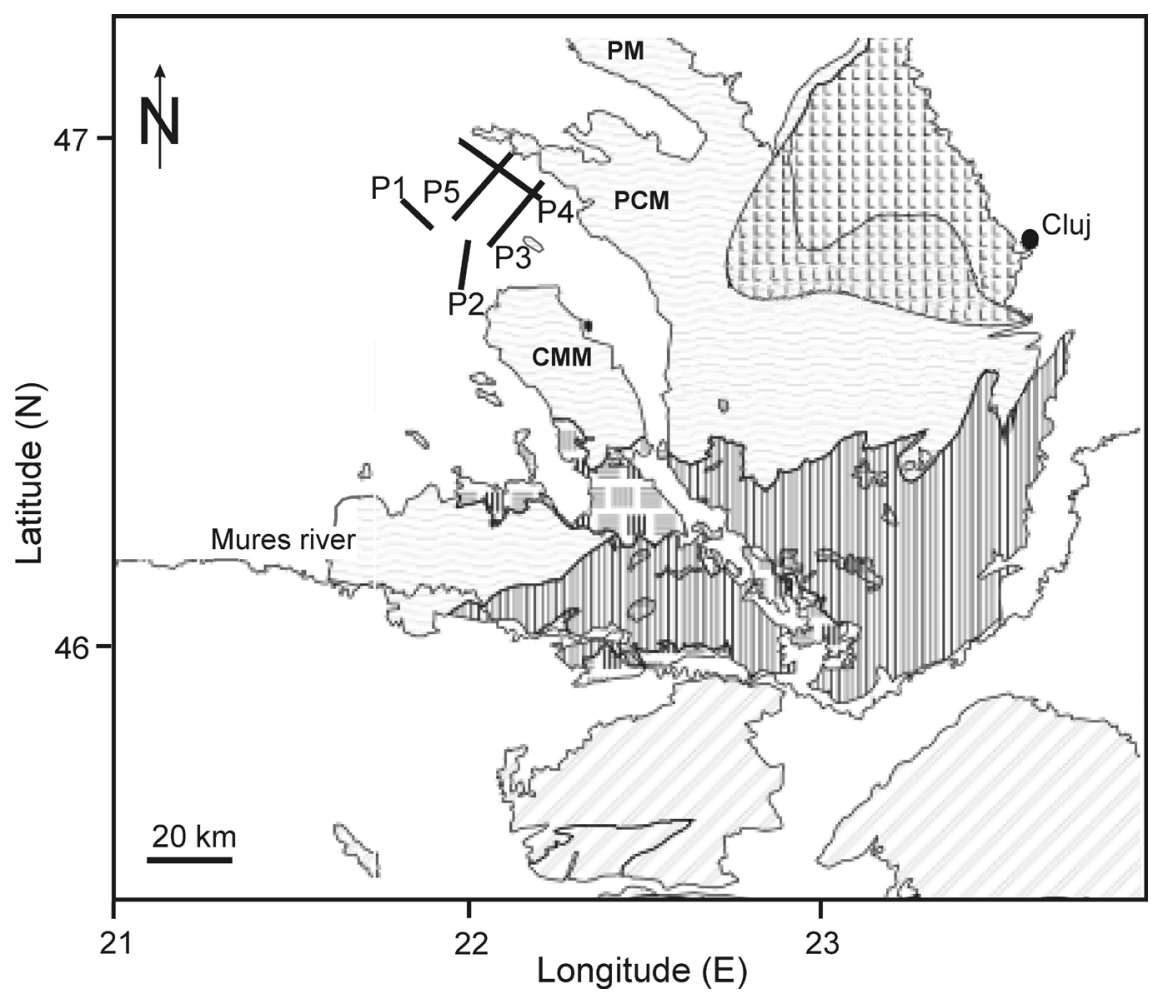

Figure 2. Tectonic map of the Apuseni Mts, Romania, showing the position of the seismic lines P1 - P5; PM-Plopis Mt., PCM-PadureaCraiului Mt., CMM-CodruMoma Mt.

a result of the closure of the Transylvanian Ocean, considered a branch of the Tethys Ocean. The differences observed in the Pre-Neogene geological evolution of these mountains allowed their separation into two main units: the North Apuseni Mts (NA Mts) and the South Apuseni Mts (SA Mts). The NA Mts have a basement which contains Early Proterozoic metamorphic rocks and Paleozoic 
magmatic rocks (granites of Late Cambrian, Middle to Late Devoinian and Early Permian ages) covered by Permo-Mesozoic sedimentary and volcanic deposits [6].

The SA Mts contain Middle Jurassic ophiolites, Late Jurassic calc-alkaline volcanic rocks and Late Jurassic to Late Cretaceous sedimentary deposits stacked within several north-verging nappes [6]. The Late Cretaceous-Paleogene magmatism developed along a north-south alignment crossed all tectonic units of the Apuseni Mts. The sedimentation process was interrupted during Paleocene-Early-Middle Miocene, the whole area being tectonic uplifted. During the Miocene times, extensional graben-like structures opened along the western edges of the Apuseni Mts [4] [7]. Starting with the Badenian age, the Apuseni Mts remained as a high relief tectonic unit after the subsidence of the surrounding basins, namely the Pannonian and Transylvanian basins [6]. From Pliocene until present times, the Apuseni Mts are gradually eroded; deposits with a thickness of about $1000 \mathrm{~m}$ were removed by erosion.

The Beius Basin is a result of the Middle Miocene extension, being made up of Middle Miocene, Pannonian and Quaternary deposits which overlap the heterogeneous basement of the NA Mts. The basement of the basin contains Mesozoic, Paleozoic and Proterozoic deposits belonging to the Bihor Autochtonous tectonic unit, the Codru and Biharia nappe systems [3]. The Bihor Autochtonous unit contains meso- and epi-metamorphic rocks and sedimentary rocks of Cretaceous, Jurassic and Triassic ages. The Codru nappe system contains nappes from the Padurea Craiului, the Bihor, the Codru Moma and Highis Mts. The nappes from the Padurea Craiului Mt. contain Permian, Triassic, Jurassic and Cretaceous deposits. The nappes from the Codru Moma Mt. contain crystalline formations and Permian, Triassic, Jurassic and Cretaceous deposits. The tectonic setting and the presence of many compartments in different positions (uplifted or downgoing) make very difficult a correlation of these units beneath the basin deposits [3]. Only few boreholes drilled for hydrocarbon exploration and exploitation pierced the Neogene deposits. From a stratigraphic point of view, the basin deposits belong to the Badenian, the Sarmatian, the Pannonian and the Quaternary ages [3]. The Badenian deposits were split into a lower detritic complex, which contains sands, gravel and conglomerates, and an upper organic complex, which contains algal and coral limestones. The Sarmatian deposits contain detritic-organic limestone, marls, clays and fine sands alternating with pelitical rocks. The Pannonian deposits are developed in the entire basin and contain sands, marls and gravels. The Quaternary deposits contain formations with different facies, such as alluvial deposits along the main rivers.

\section{Description of the Seismic Data Acquisition}

I analyzed vintage seismic reflection data recorded in studies for hydrocarbon exploration. Five seismic reflection data sets were selected for further structural and tectonic analyses. The seismic data were recorded along lines with uniform 
distribution over the study area (lines P1 - P5 in Figure 2). The seismic measurements were performed more than 20 years ago using short geophone spread per shot point. The recordings were performed using an active spread of 96 geophones for each shot point in a split-spread pattern; additional shot points were designed on both edges of the lines using end-on and asymmetrical split-spread layouts in order to increase the fold on these segments of the lines. The geophone spacing was about $25 \mathrm{~m}$. Explosive sources were used to generate the seismic energy in points spaced at about $50 \mathrm{~m}$. Irregular spacing between sources and geophones reflected into fold variation along each seismic line. Time sampling interval was $0.002 \mathrm{~s}$, which means a Nyquist frequency of $250 \mathrm{~Hz}$. Record length was $4 \mathrm{~s}$. The seismic measurements were performed over an area with rough topography and difficult access to the acquisition lines, especially for the lines P3 - P5, which affected the quality of the shot gathers. I display in Figure 3 the elevation profiles for all lines. An example of shot gather recorded using a geophone spread along which the elevation values have significant variations is displayed in Figure 4(a); its frequency-wavenumber ( $\mathrm{f}-\mathrm{k})$ amplitude spectrum is displayed in Figure 4(b). The analysis of the surface, reflected and refracted waves was done in the $\mathrm{f}-\mathrm{k}$ domain. The head waves and the surface waves are affected by spatial aliasing, due to the use of geophone spacing of 25 $\mathrm{m}$. Extra spatially-aliased energy was introduced by irregular geophone spacing, lateral variation in velocities of weathered layers and rough topography. The spatially-aliased energy is indicated by the dipping lines on both directions seen on the spectrum from Figure 4(b).

The application of refraction static corrections during the data processing will partially attenuate the spatially-aliased energy seen on the f-k amplitude spectra of the shot gathers.

\section{Analysis and Processing of Seismic Reflection Data}

The seismic data processing was done following a standard flow. For each line, the input data are represented by shot gathers saved in the SEG-Y format. The number of shot gathers in each data set varies from one data set to another. The geometry was defined for linear profiles. For all data sets, the refraction static corrections were computed for a final datum at $+400 \mathrm{~m}$ and using replacement velocities determined after the head wave analysis. Frequency filtering was performed using f-k filters, band-pass frequency filters and predictive deconvolution applied with different parameters, as determined after the data analysis in the $\mathrm{f}-\mathrm{k}$ domain. The traces from the filtered shot gathers were sorted after the common-depth-point (CDP) numbers in order to create CDP-gathers, which are the input data for the interactive velocity analysis. The results of the velocity analysis are represented by stacking velocity models. The following data processing steps, namely the normal moveout correction, prestack time migration using the Kirchhoff method, stacking of traces and time-to-depth conversion were performed using stacking and interval velocity models. The interval velocity models 

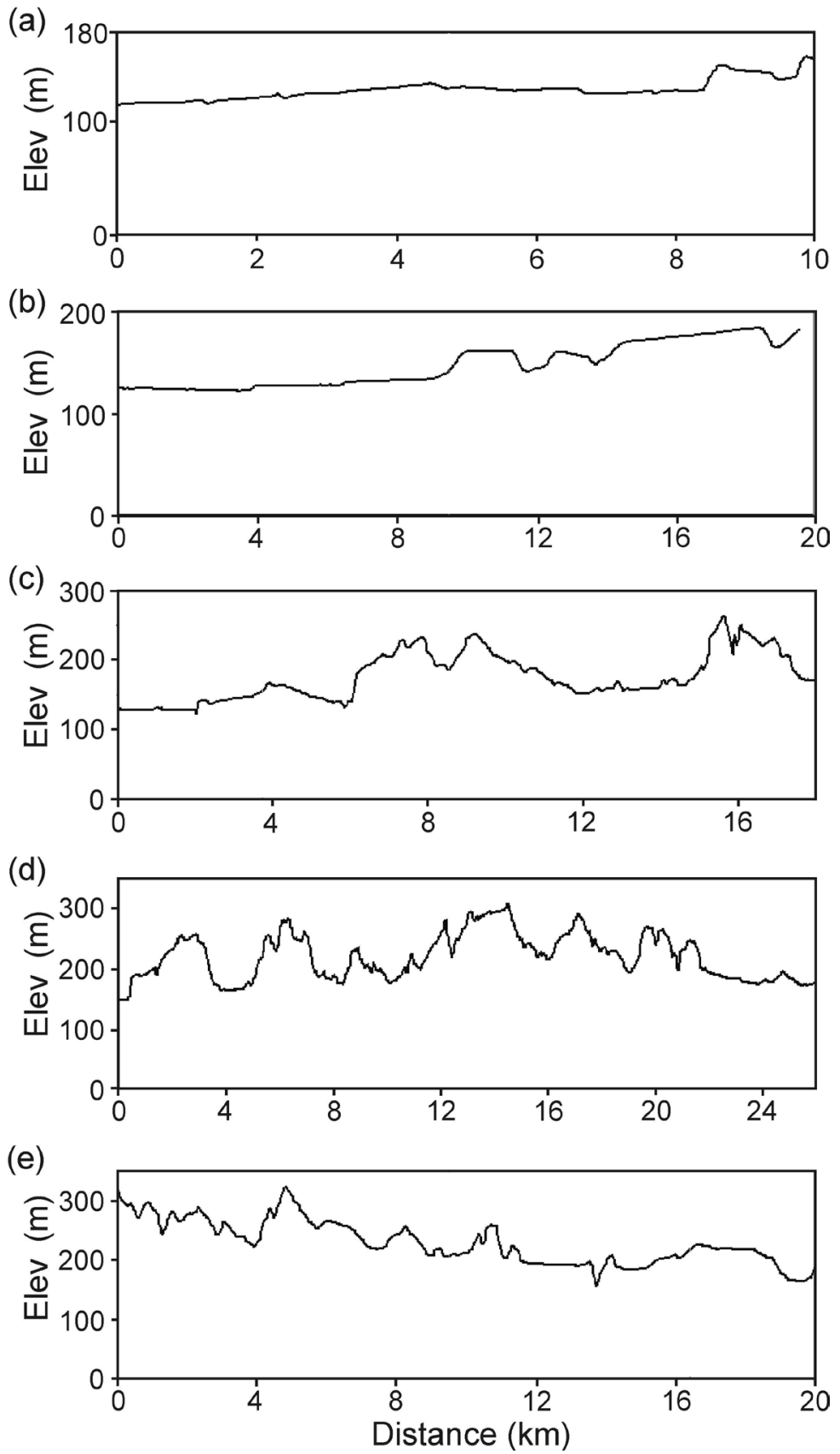

Figure 3. Elevation profile for the line (a) P1, (b) P2, (c) P3, (d) P4 and (e) P5.

were obtained from the stacking velocity models, after conversion followed by some editing of anomalous velocity values seen on the resulted interval velocity models.

The data set recorded along the line P1 contains 188 shot gathers. Shot gathers with clear reflections were recorded on the northwestern half of the line, where the sedimentary deposits are thicker than toward southeast (Figure 5(a)). Most of the shot gathers recorded on the southeast part of the seismic line contain a clear reflection coming from the top of basement; an example of shot gather is displayed in Figure 5(b). 

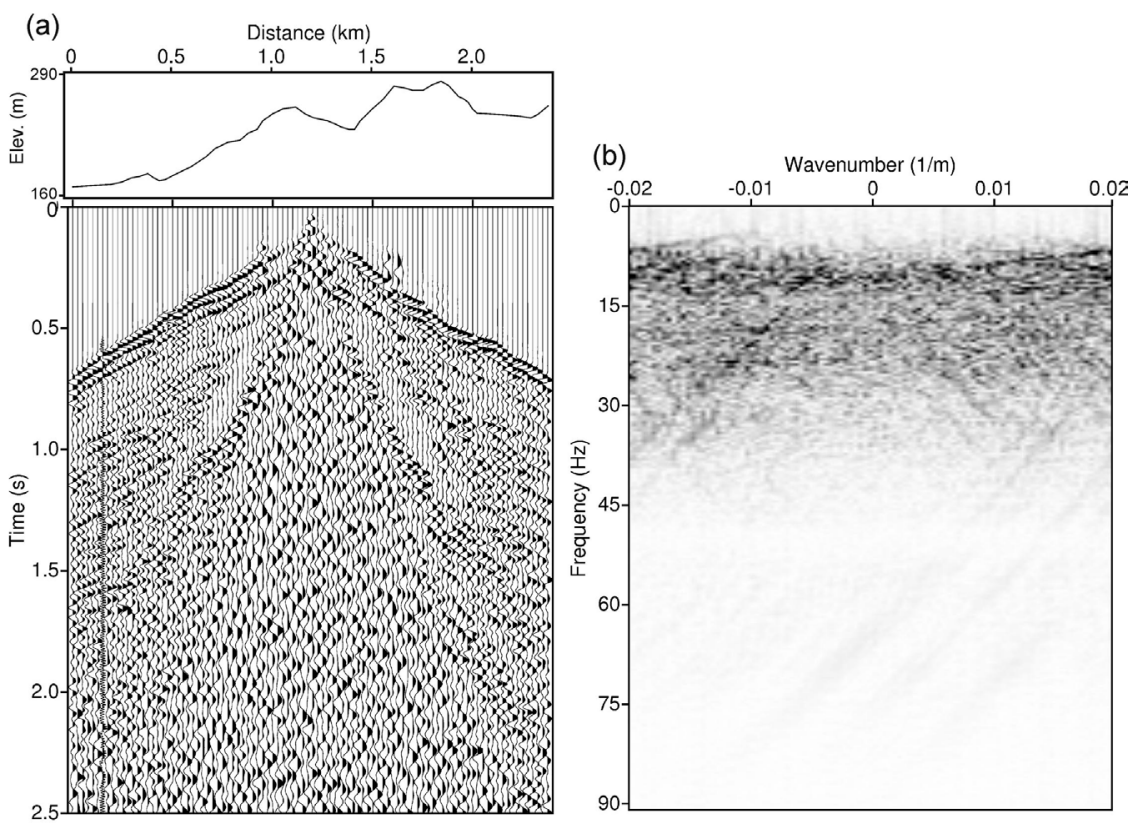

Figure 4. Raw shot gather displayed in (a) the time-distance domain, with the elevation profile on top of it, and (b) its frequency-wavenumber amplitude spectrum.

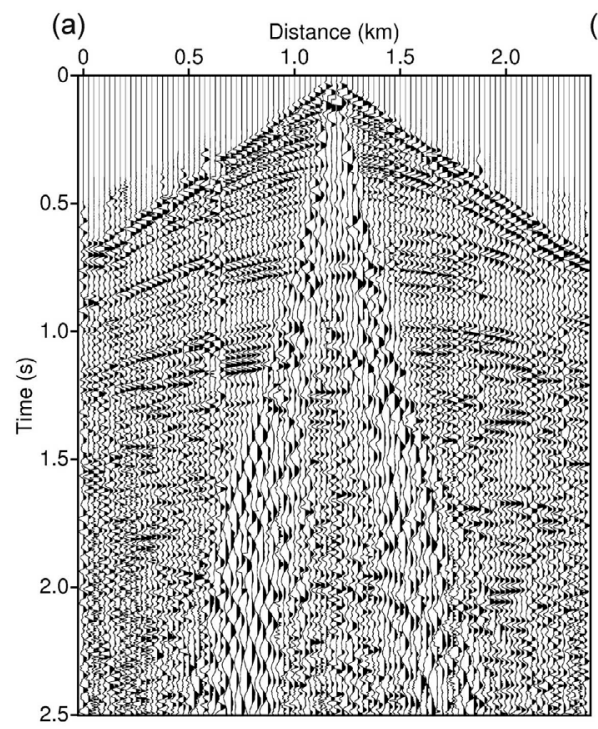

(b)

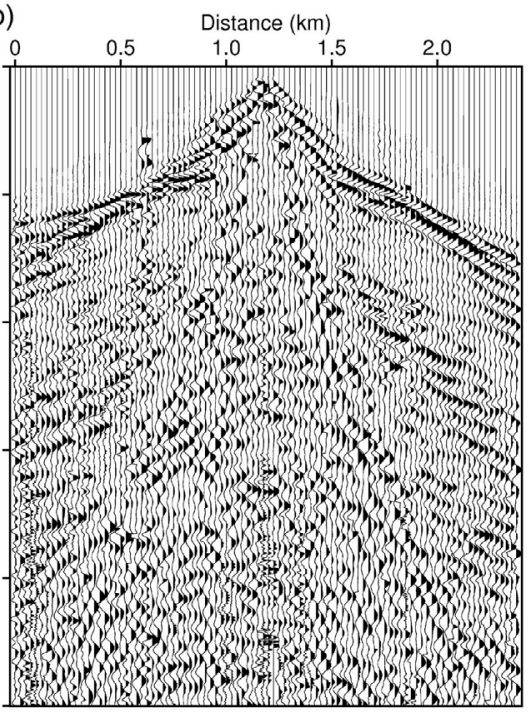

Figure 5. Shot gathers recorded on the (a) northwest and (b) southeast parts of the line P1 displayed in the time-distance domain.

After the application of refraction static corrections, the surface waves were removed using the $\mathrm{f}-\mathrm{k}$ filtering, the band-pass frequency filtering for $18-60 \mathrm{~Hz}$, and predictive deconvolution. The migrated seismic section was converted to a depth seismic section using the velocities obtained after the interactive velocity analysis performed on filtered CDP-gathers.

The data set recorded along the line P2 contains 372 shot gathers. The data quality varies along the line. An example of raw shot gather with clear reflections is displayed in Figure 6(a). The lack of interpretable reflections on the shot 

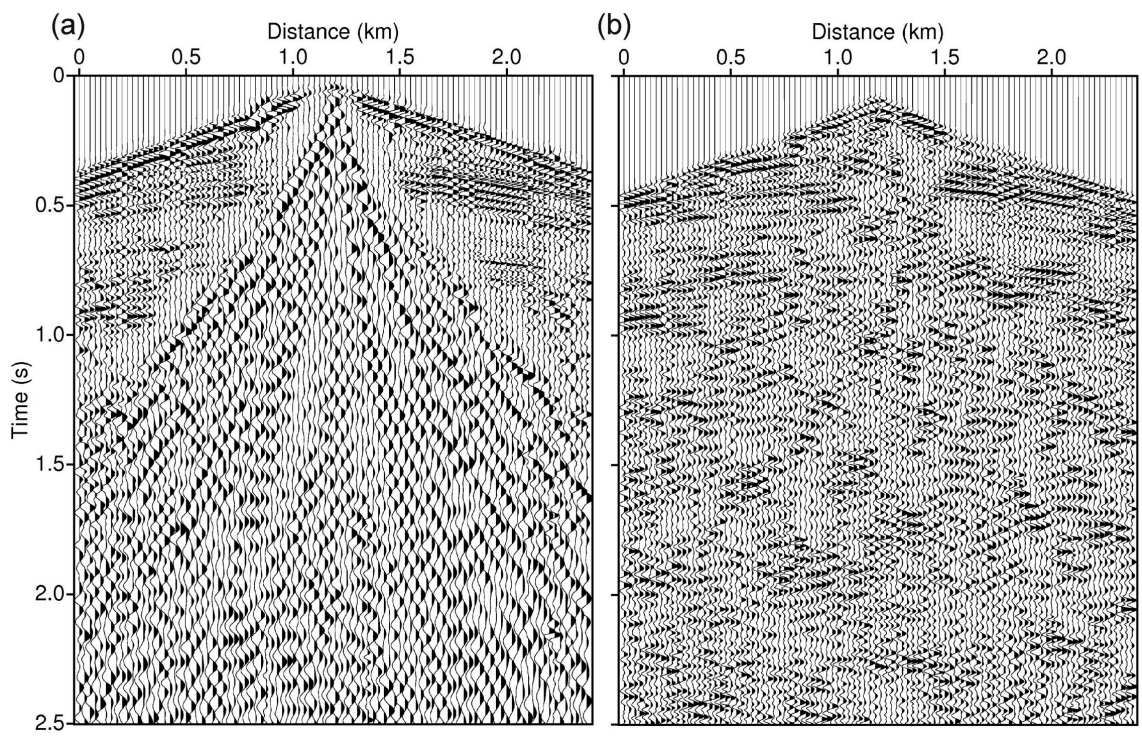

Figure 6. Shot gather recorded along the line P2 (a) before and (b) after the frequency filtering.

gathers recorded on the southern half of the seismic line is explained by the presence of thin sedimentary deposits which cover the shallow basement units. After the application of refraction static corrections, the coherent noise was removed using the f-k filtering, the band-pass frequency filtering for $18-66 \mathrm{~Hz}$, and predictive deconvolution (Figure 6(b)). Some of the filtered shot gathers contain remaining spatially-aliased surface waves. These waves will be partially attenuated during the stacking of the filtered traces sorted after CDP numbers. The time-to-depth conversion was done after migration and stacking of traces.

The data set recorded along the line P3 contains 322 shot gathers. Most of the shot gathers are characterized by low signal-to-noise ratio as an effect of various factors, such as complex subsurface geology, rough topography and noise generated along the line during data recordings. I display in Figure 7(a) an example of good shot gather recorded in the presence of significant variations in elevation along the geophone spread. Surface waves are spatially aliased and strong in amplitude. Their removal was performed, after the application of refraction static corrections, using f-k filtering, band-pass frequency filtering for 18 - 46 $\mathrm{Hz}$, and predictive deconvolution. The filtered version of the record from Figure 7(a) is displayed in Figure 7(b); clear reflections are seen after the frequency filtering. All filtered records were used to obtain a depth-converted migrated seismic section.

The data set recorded along the line P4 contains 477 shot gathers, most of them being characterized by low signal-to-noise ratio. The recordings were performed over an area with rough topography (Figure 2(d)). An example of good record, before and after the frequency filtering, is displayed in Figure 8. The coherent noise was removed using $\mathrm{f}-\mathrm{k}$ filtering, band-pass frequency filtering for $18-46 \mathrm{~Hz}$, and predictive deconvolution. The low quality of shot gathers reflected into the noisy image of the depth-converted migrated seismic section. 

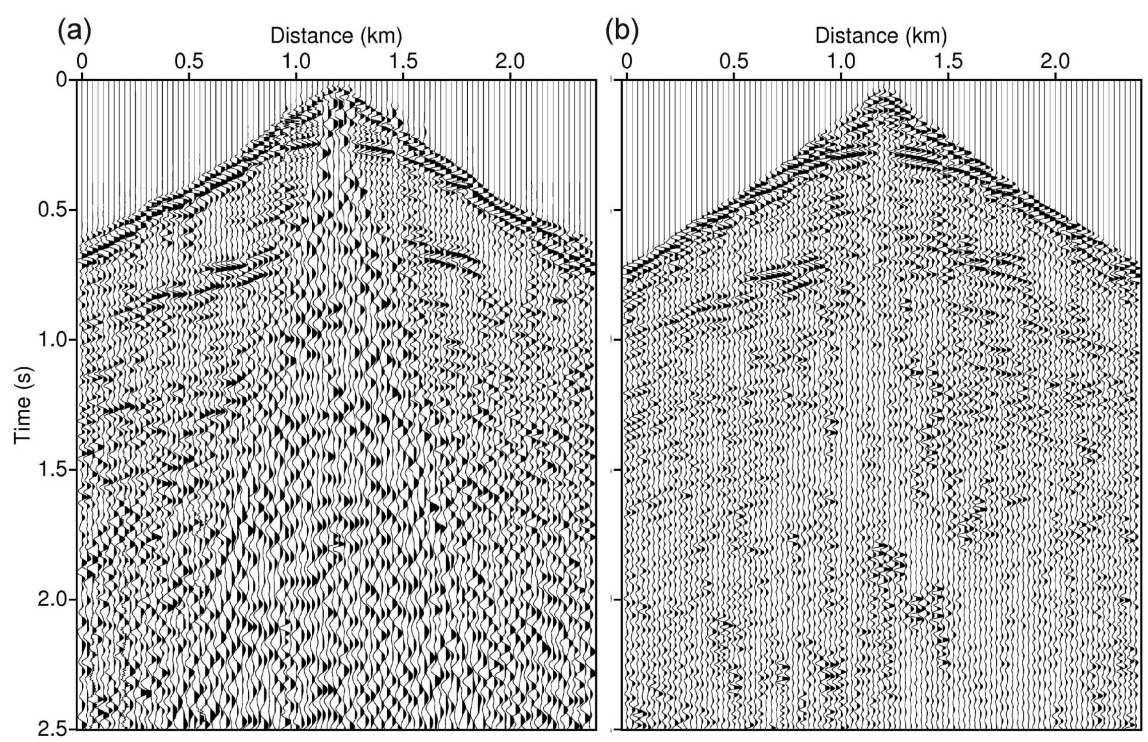

Figure 7. Shot gather recorded along the line P3 (a) before and (b) after the frequency filtering.
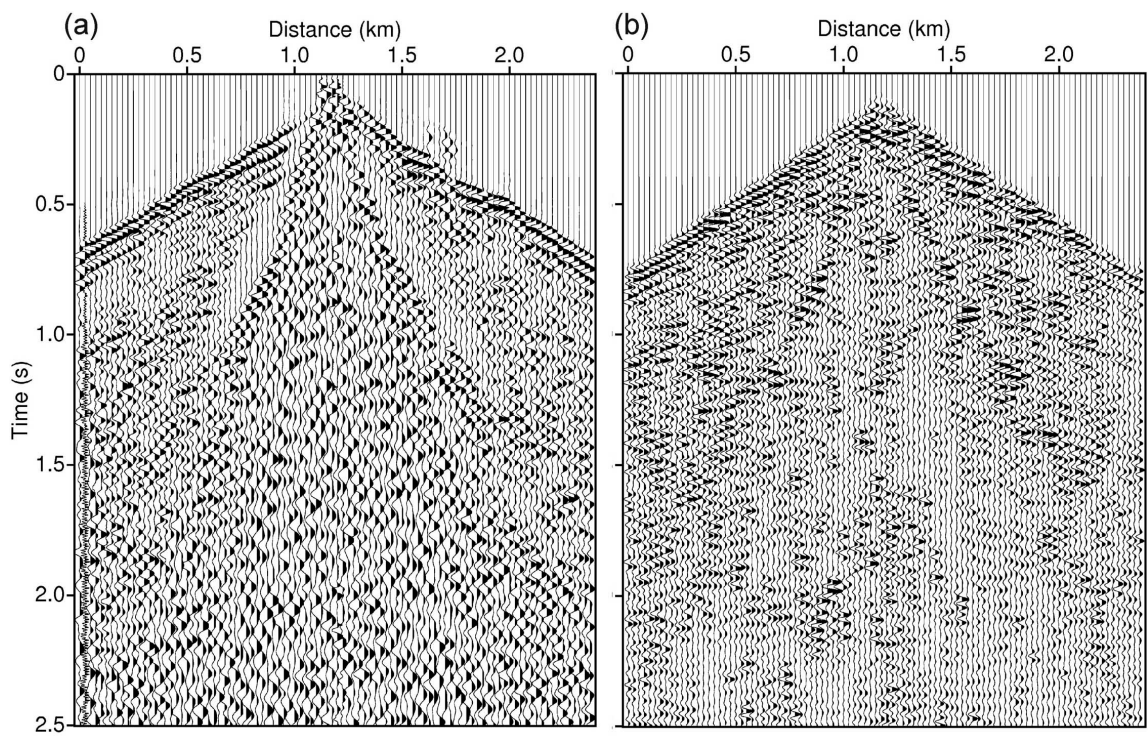

Figure 8. Shot gather recorded along the line P4 (a) before and (b) after the frequency filtering.

The data set recorded along the line P5 contains 394 shot gathers. Most of them contain weak reflections and noise generated during recordings along the line. An example of good record is displayed in Figure 9(a). After the application of refraction static corrections, the coherent noise was removed using $\mathrm{f}-\mathrm{k}$ filtering, band-pass frequency filtering for $16-46 \mathrm{~Hz}$, and predictive deconvolution. Clear reflections can be seen on the filtered version of the record from Figure 9(a) (see Figure 9(b)). The presence of reflections on the filtered CDP-gathers allows the picking of reliable stacking velocities used later for time migration, stacking of traces and time-to-depth conversion. 


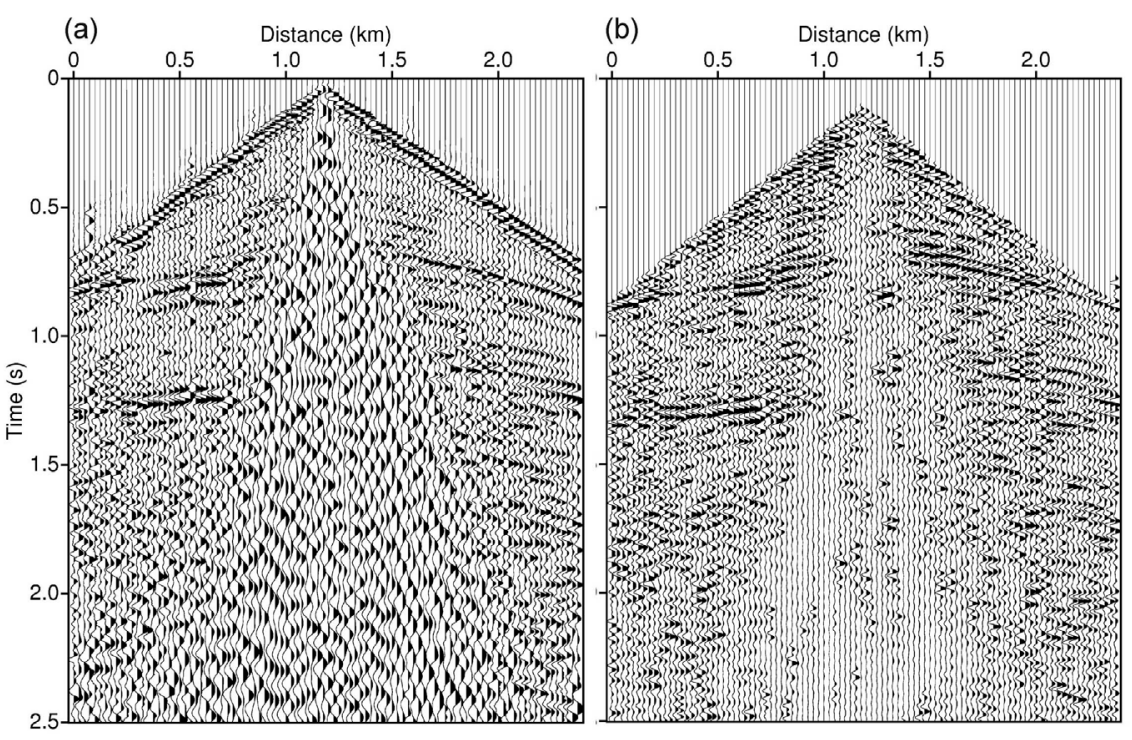

Figure 9. Shot gather recorded along the line P5 (a) before and (b) after the frequency filtering.

\section{Results and Discussions}

Time and depth-converted seismic sections provide accurate information about the geological structure of the subsurface. When available, velocity data measured in wells can be used to verify the accuracy of the time-to-depth conversion of the seismic data. Seismic sections obtained after processing of seismic reflection data recorded using active spreads per shot points with 48 and 96 channels were used by [2] in the analysis of the tectonic and stratigraphic evolution of the northern part of the Pannonian Basin. Additional structural information is provided by the interpretation of the vintage seismic data presented in this study.

The line P1 has a northwest to southeast orientation and a length of about 10 $\mathrm{km}$. The uninterpreted depth-converted migrated seismic section is displayed in Figure 10(a). The thickness of the sedimentary deposits decreases from about $900 \mathrm{~m}$, in northwest, to $200 \mathrm{~m}$, in southeast. Two seismic sequences separated by a strong reflector can be interpreted on the seismic section. The strong reflector indicates an erosional surface, also identified by [2]. The upper sequence contains horizontal, parallel, thin reflectors characterized by weak amplitudes. Thin sedimentary layers can be interpreted inside this sequence. According to the geological map known for this area, these deposits might be of Upper Pannonian to Quaternary ages. The spatially-aliased surface waves remained after the frequency filtering applied during data processing interfered with the reflectors from this sequence and affected their continuity and amplitude (Figure 10(b)). The lower sequence contains inclined reflectors with toplap and truncation terminations. During and after the Pannonian sedimentation, the area was active from a tectonic point of view being affected by erosion [2]. The amplitude reflectors vary from strong amplitude, at distances of $0-2 \mathrm{~km}$ on the seismic section, to weak amplitude, at distances of 2 - $10 \mathrm{~km}$ (Figure 10(b)). Apart of possible 


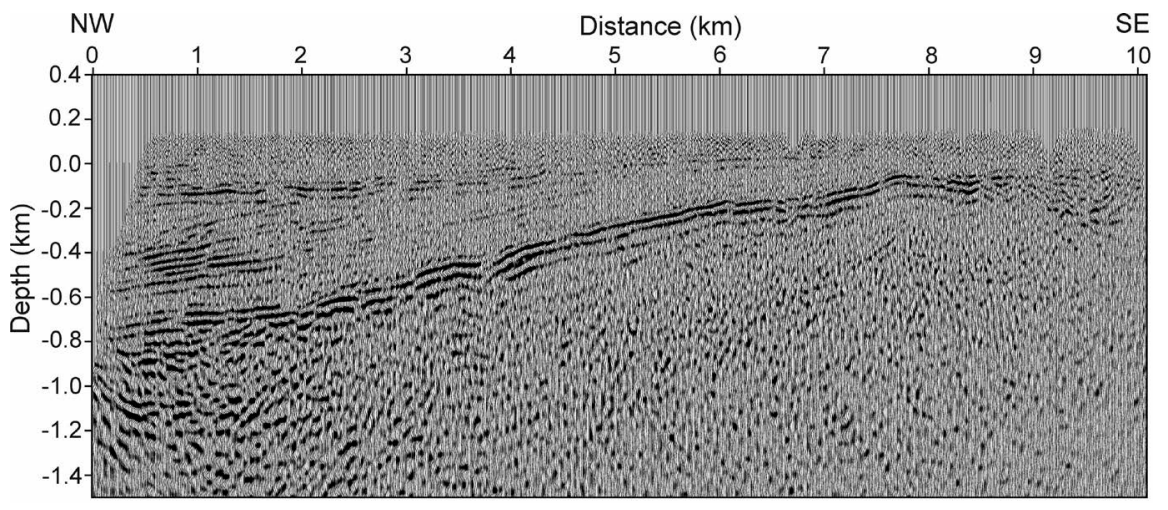

(a)

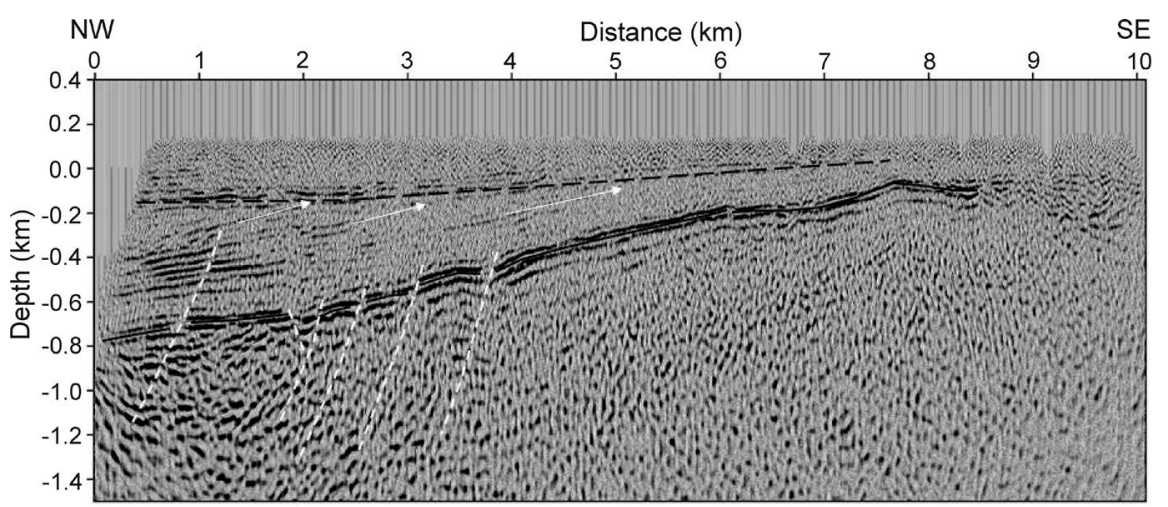

(b)

Figure 10. (a) Uninterpreted depth-converted migrated seismic section obtained for the line P1; (b) Interpreted depth-converted migrated seismic section obtained for the line P1; dashed white lines-Middle Miocene faults, dashed black line-interface between seismic sequences, solid black line-top of the basement, white arrows-toplap and truncation terminations.

weak differentiation in lithology between layers reflected into weak contrast in acoustic impedance, the presence of weak-amplitude reflectors might be an effect of the presence of noisy shot gathers recorded on this distance interval. The thickness of the sedimentary deposits from the lower sequence decreases from northwest to southeast, where the basement units of the Codru Moma Mts are imaged at depths of about $200 \mathrm{~m}$. A series of Middle Miocene normal faults which affected the basement units and the deepest sedimentary layers are interpreted on the seismic section.

The line P2 has a north to south orientation and a length of about $19 \mathrm{~km}$. The uninterpreted depth-converted migrated seismic section is displayed in Figure 11(a). The upper seismic sequence interpreted on the seismic section from Figure 10 (b) can be also interpreted on the seismic section obtained for the line P2, indicating the presence of similar sedimentary environments (Figure 11(b)). Thin parallel reflectors characterized by good continuity and amplitudes are interpreted on distances of $0-10 \mathrm{~km}$ along the seismic section. The thickness of this sequence decreases to about $100 \mathrm{~m}$ at distances of $12-19 \mathrm{~km}$, where the basement units of the Codru Moma Mts are imaged at shallow depths. Reflector 


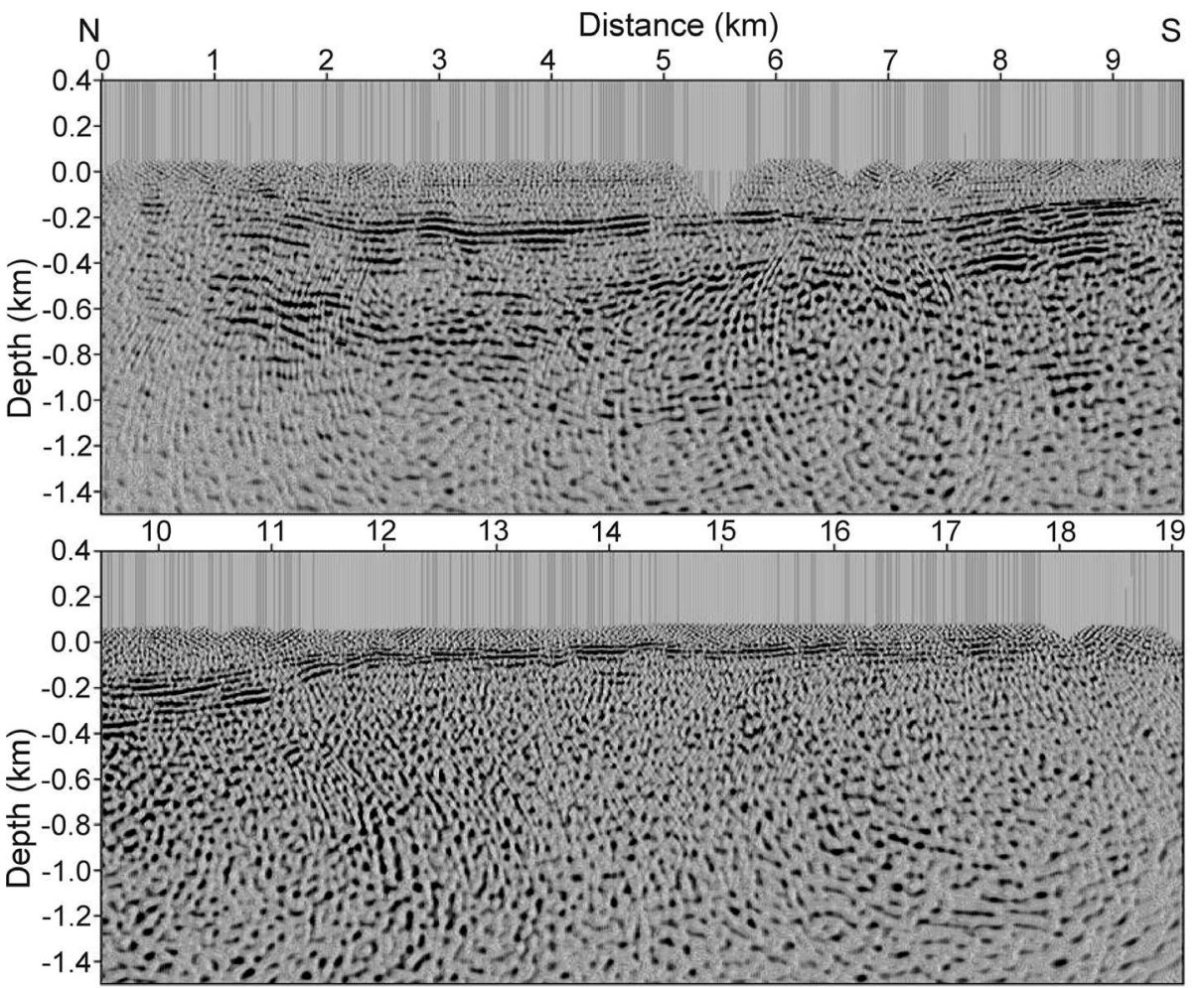

(a)
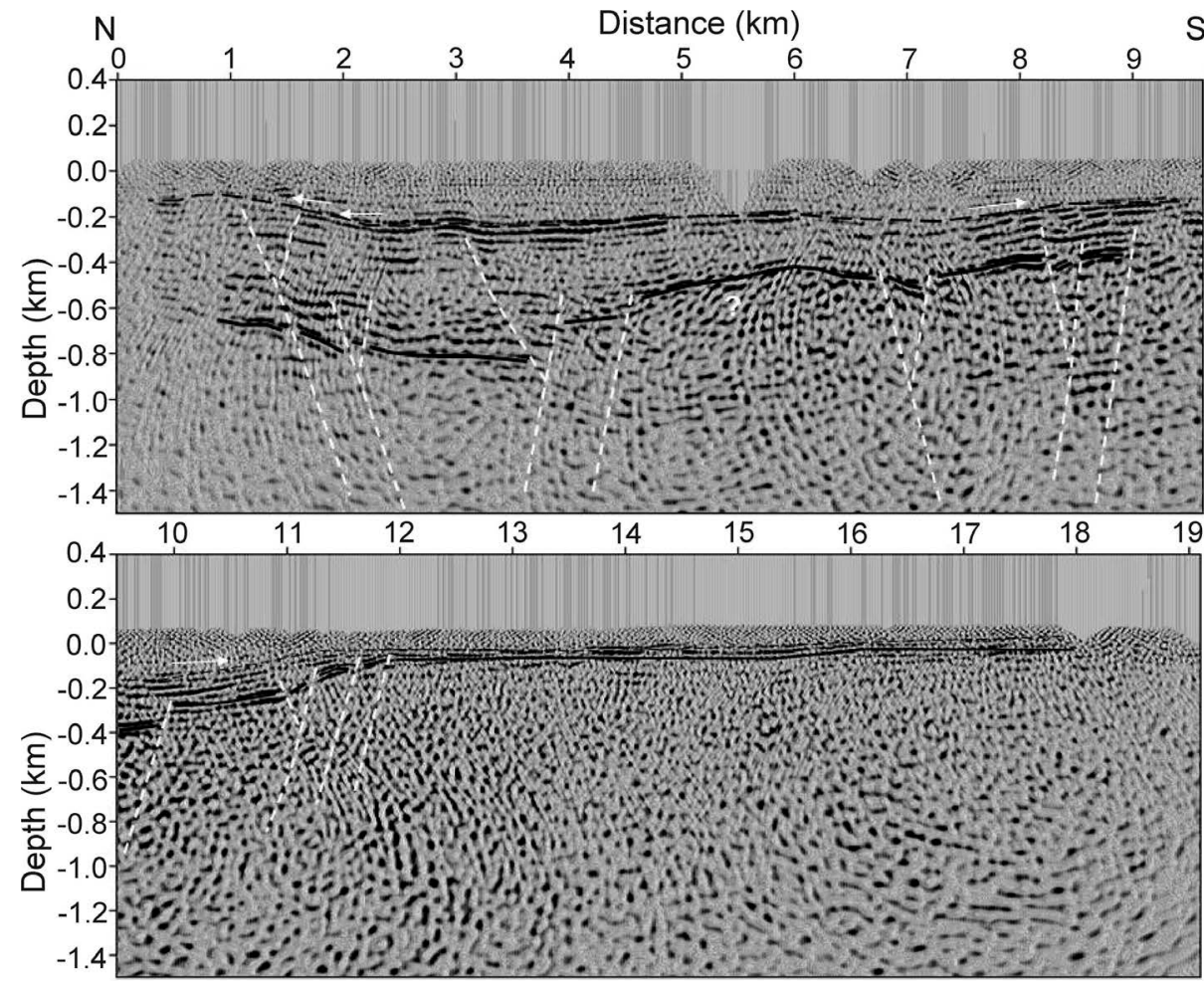

(b)

Figure 11. (a) Uninterpreted depth-converted migrated seismic section obtained for the line P2; (b) Interpreted depth-converted migrated seismic section obtained for the line P2; dashed white lines-reactivated Middle Miocene faults, dashed black line-interface between seismic sequences, solid black line-top of the basement, white arrows-onlap terminations. 
terminations of onlap type can be interpreted on distances of 0 - $3 \mathrm{~km}$ and 7.5 $11 \mathrm{~km}$ indicating an increasing of the sedimentary area. This sequence might contain sedimentary deposits of Upper Pannonian to Quaternary ages. Locally, spatially-aliased surface waves remained after frequency filtering affected the continuity of the thin reflectors. The lower seismic sequence contains reflectors characterized by weak amplitudes and interrupted continuity. The sedimentary deposits might be of Middle and Late Miocene ages. The interpreted faults might be Middle Miocene normal faults reactivated during Pannonian, since the sedimentary deposits of Middle and Late Miocene ages are involved in deformations. The interpretation of the top of the basement is unclear on distances of $0-9 \mathrm{~km}$, where only pieces of reflectors can be followed. For the rest of seismic section, the top of the basement is given by a strong reflector in amplitude. The basement units of the Codru Moma Mts are imaged at shallow depths at distances of $12-19 \mathrm{~km}$.

The line P3 has a northeast to southwest orientation and a length of about 17 $\mathrm{km}$. The uninterpreted depth-converted migrated seismic section is displayed in Figure 12(a). A seismic sequence with undeformed and inclined parallel reflectors is interpreted on the northeastern half of the seismic section (Figure 12(b)). These sedimentary deposits might be of Pannonian to Quaternary ages, according to the geological description of the area in [2]. The thickness of this sequence is about $500 \mathrm{~m}$, in its northeastern end, and decreases to less than $100 \mathrm{~m}$ toward southwest. The reflectors interpreted below this sequence, characterized by strong amplitudes, might indicate the presence of the Badenian-Sarmatian deposits. The interpretation of the seismic section is unclear toward southwest. What is sure is that the basement units of the Codru Moma Mts. are imaged at shallow depths. The lack of a clear reflector from the top of the basement along the entire seismic section might be considered to be an effect of the low-quality seismic data recorded along this line combined with the rough topography of the top of the basement. Intrusive bodies with the lateral parts very inclined were interpreted on distances of $8.2-9.2 \mathrm{~km}, 11.7-12.5 \mathrm{~km}$ and, probably, $14.7-16 \mathrm{~km}$ (solid white lines in Figure 12(b)). Intrusive rocks outcrop within a narrow and elongated area with a northwest to southeast orientation at southeast of the P3 line. Their prolongation into the depth toward northwest was seen on the map of the vertical gradient of the magnetic anomaly presented in [3].

The line $\mathrm{P} 4$ has a northwest to southeast orientation and a length of about 26 $\mathrm{km}$, being parallel to the southwestern border of the Padurea Craiului Mts. The uninterpreted depth-converted migrated seismic section is displayed in Figure 13(a). A seismic sequence with deformed and discontinuous thin reflectors is interpreted along the entire line. Its thickness varies from few hundreds of meters to less than $100 \mathrm{~m}$ (Figure 13(b)). The sedimentary deposits might be of Late Miocene age, according to the geological model presented in Rabagia (2009). The strong reflectors in amplitude which occur locally beneath the upper sequence might represent Badenian-Sarmatian deposits. The pieces of reflectors imaged on the entire seismic section might be considered evidences of important 

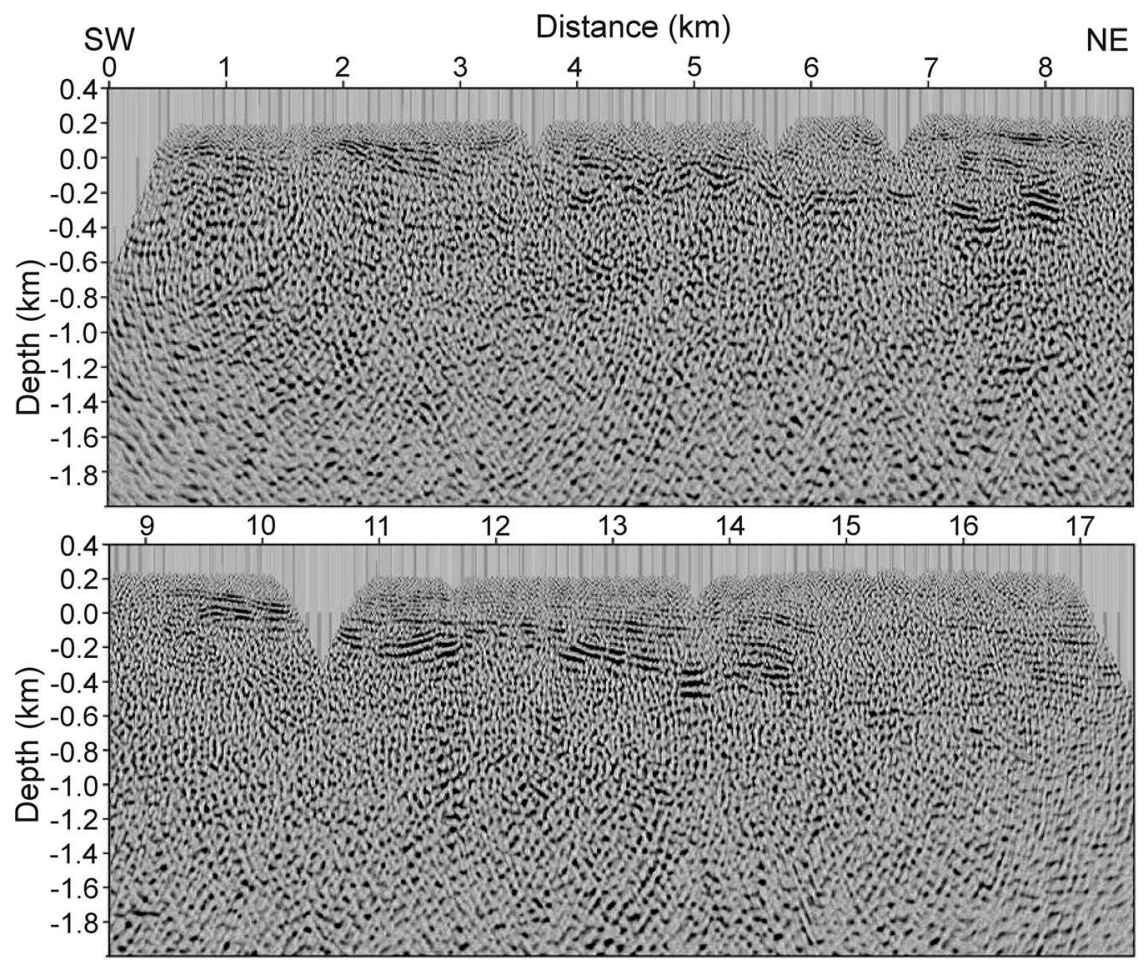

(a)
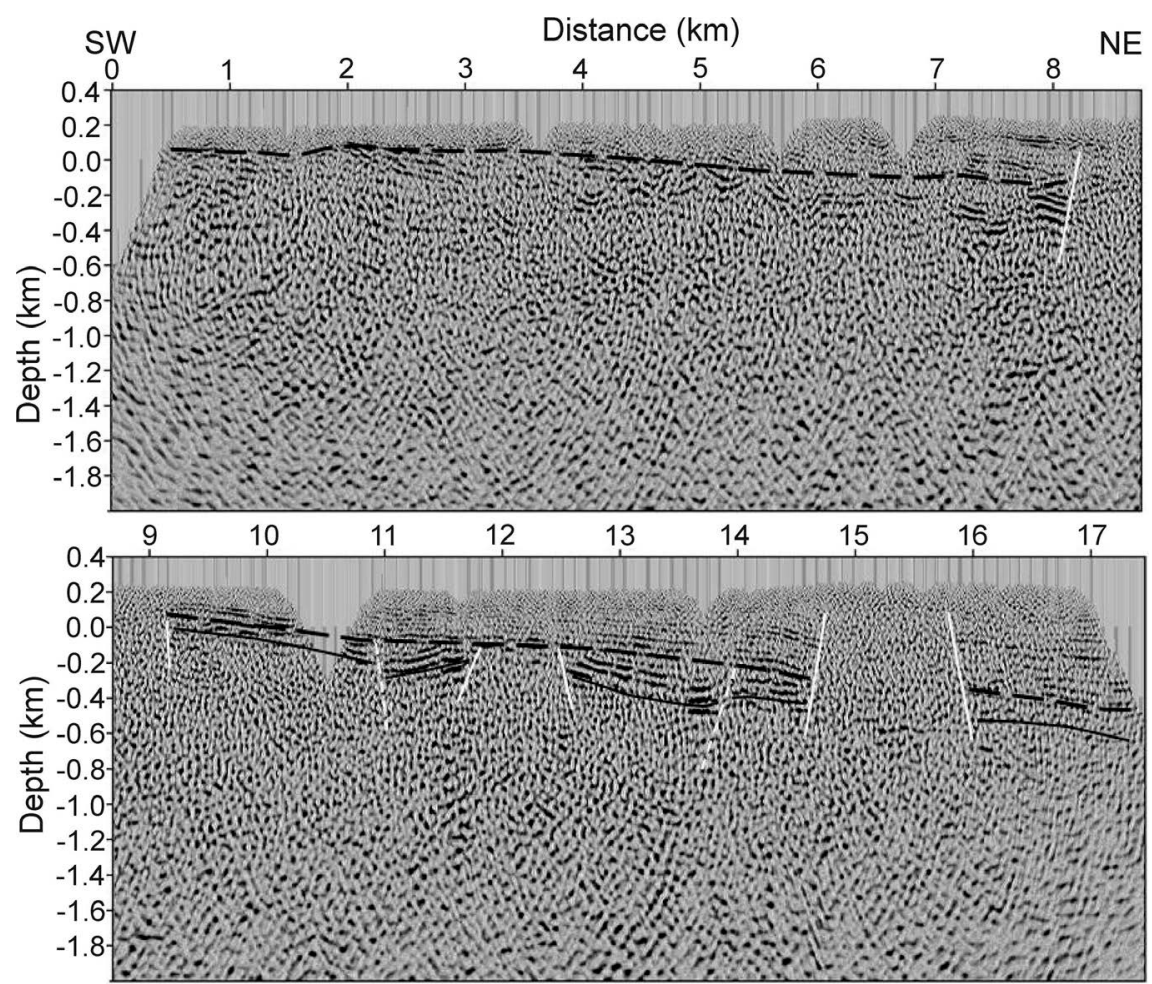

(b)

Figure 12. (a) Uninterpreted depth-converted migrated seismic section obtained for the line P3; (b) Interpreted depth-converted migrated seismic section obtained for the line P3; dashed white lines-Middle Miocene faults, solid white line-edges of intrusive bodies, dashed black line-interface between seismic sequences, solid black line-top of the basement. 


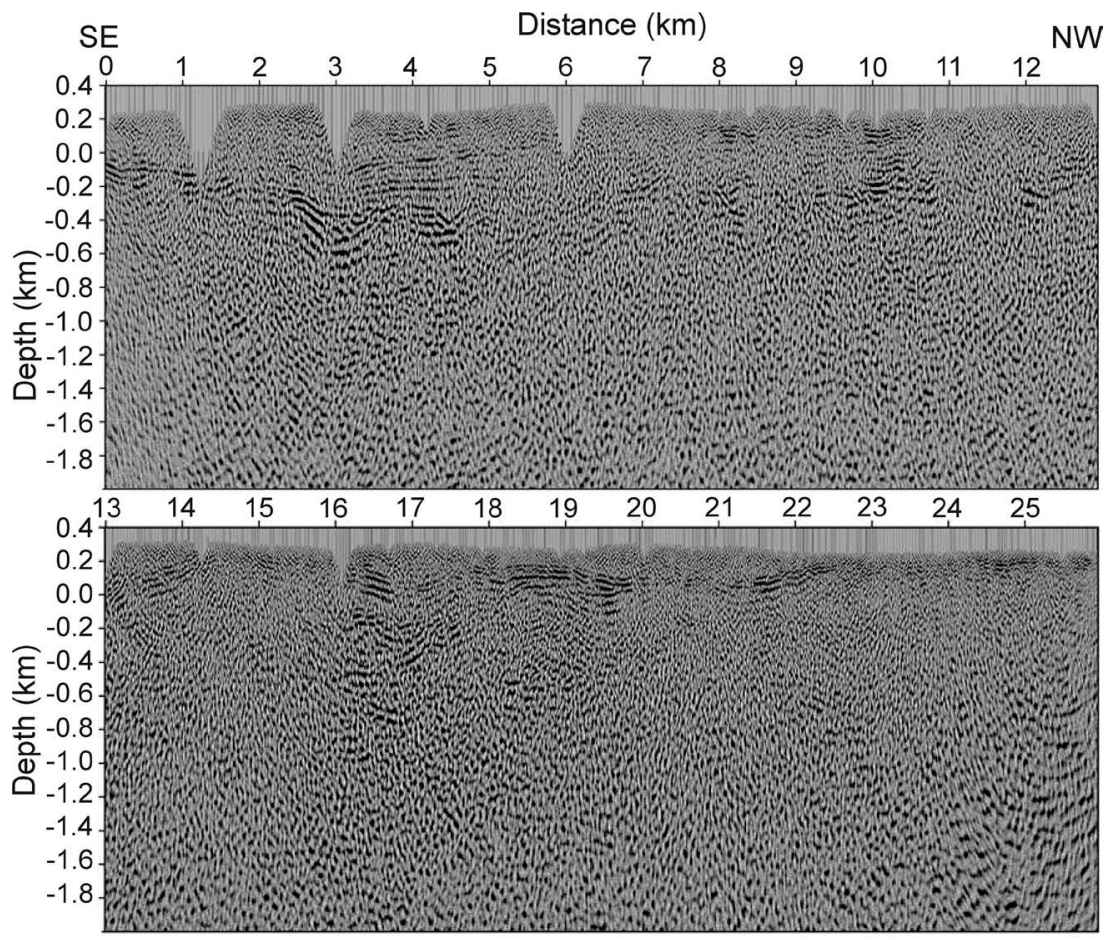

(a)
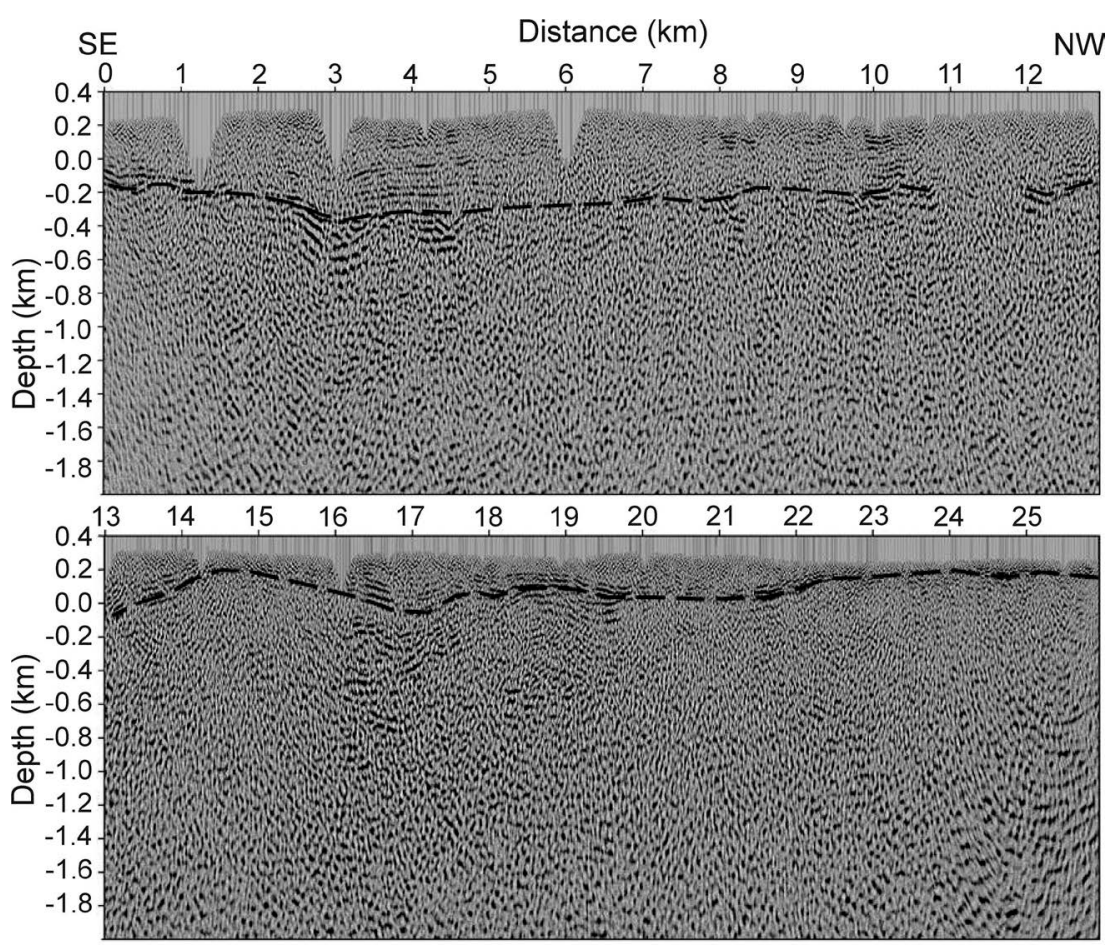

(b)

Figure 13. (a) Uninterpreted depth-converted migrated seismic section obtained for the line P4; (b) Interpreted depth-converted migrated seismic section obtained for the line P4; dashed black line-interface between seismic sequences.

deformations, ruptural or not, which took place in this area during the inversion from the end Sarmatian and the Lower Pannonian rifting. The basement units of 
the Padurea Craiului Mts. are imaged as blocks in different positions, uplifted or downgoing, on distances of $0-2.5 \mathrm{~km}, 11-12 \mathrm{~km}, 14-16 \mathrm{~km}$ and $20-26 \mathrm{~km}$. It was difficult to interpret the top of the basement due to the absence of a reflector, or pieces of reflectors, from it.

The line P5 has a northeast to southwest orientation and a length of about 21 $\mathrm{km}$. The uninterpreted depth-converted migrated seismic section is displayed in Figure 14(a). Thin sedimentary deposits, probably of Upper Pannonian age, cover the basement units of the Padurea Craiului Mts. at distances of $0-7 \mathrm{~km}$ along the line (Figure 14(b)).

A narrow basin with sediments was interpreted at distances of $3-4 \mathrm{~km}$. The steep fault interpreted at a distance of about $7 \mathrm{~km}$ separates the Neogene sedimentary deposits of the Beius Basin from the basement units of the Padurea Craiului Mts, which act as a rift shoulder. A packet of reflectors can be seen on the distance interval of $7-10 \mathrm{~km}$ until depths of about $1 \mathrm{~km}$. Two sedimentary sequences can be interpreted, an upper one containing continuous and slightly deformed thin reflectors characterized by high amplitudes and a lower sequence in which the reflectors are characterized by weak amplitudes. The fractured top of the basement is indicated by a strong reflector (Figure 14(b)). The sedimentary deposits from the upper sequence might be of Late Miocene age, while those from the lower sequence might be of Middle Miocene age (Badenian and Sarmatian), according to [2]. The lack of reflectors at distances of $10-12 \mathrm{~km}$ and depths greater than $0 \mathrm{~m}$ might be a result of the processing of low signal-to-noise ratio seismic data. Another explanation might be the presence of an intrusive body of Permian rocks with the lateral parts very inclined in the upper side covered by thin sedimentary deposits, probably of Late Miocene age. The interpretation of the reflectors seen on the southwestern half of the seismic section is difficult to be performed in the absence of borehole data and/or other seismic data. The thin sequence of sedimentary layers might represent sedimentary deposits of Late Miocene age. The deformed reflectors seen below the depth of $0 \mathrm{~m}$ might represent sedimentary deposits of Middle Miocene age [2]. Their deformation, probably, took place during the inversion from the end of Sarmatian and the Lower Pannonian rifting when strike-slip faults were developed. The presumed top of the basement used in interpretation is affected by Middle Miocene faults.

\section{Conclusion}

I analyzed and processed vintage seismic data with the aim to obtain depthconverted migrated seismic sections that will provide useful information about the subsurface geological structure in the southern part of the North Apuseni Mts, Romania. The vintage seismic data are represented by five seismic reflection data sets. The seismic data were recorded using an active spread of 96 geophones for each shot point. The length of the acquisition lines varied from 10 $\mathrm{km}$ to $26 \mathrm{~km}$. The signal-to-noise ratio of the shot gathers varies along the acquisition lines as an effect of the complex subsurface geology, rough topography 

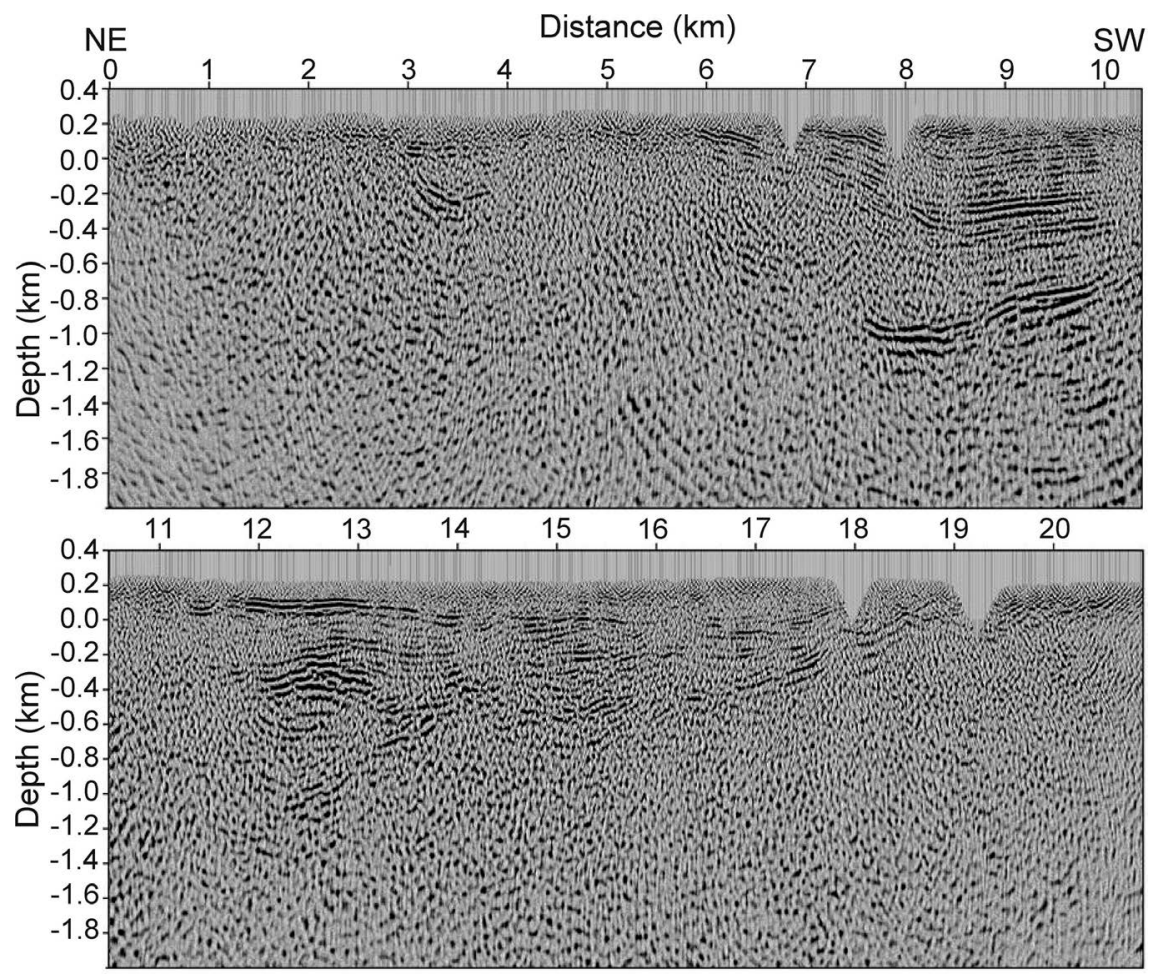

(a)
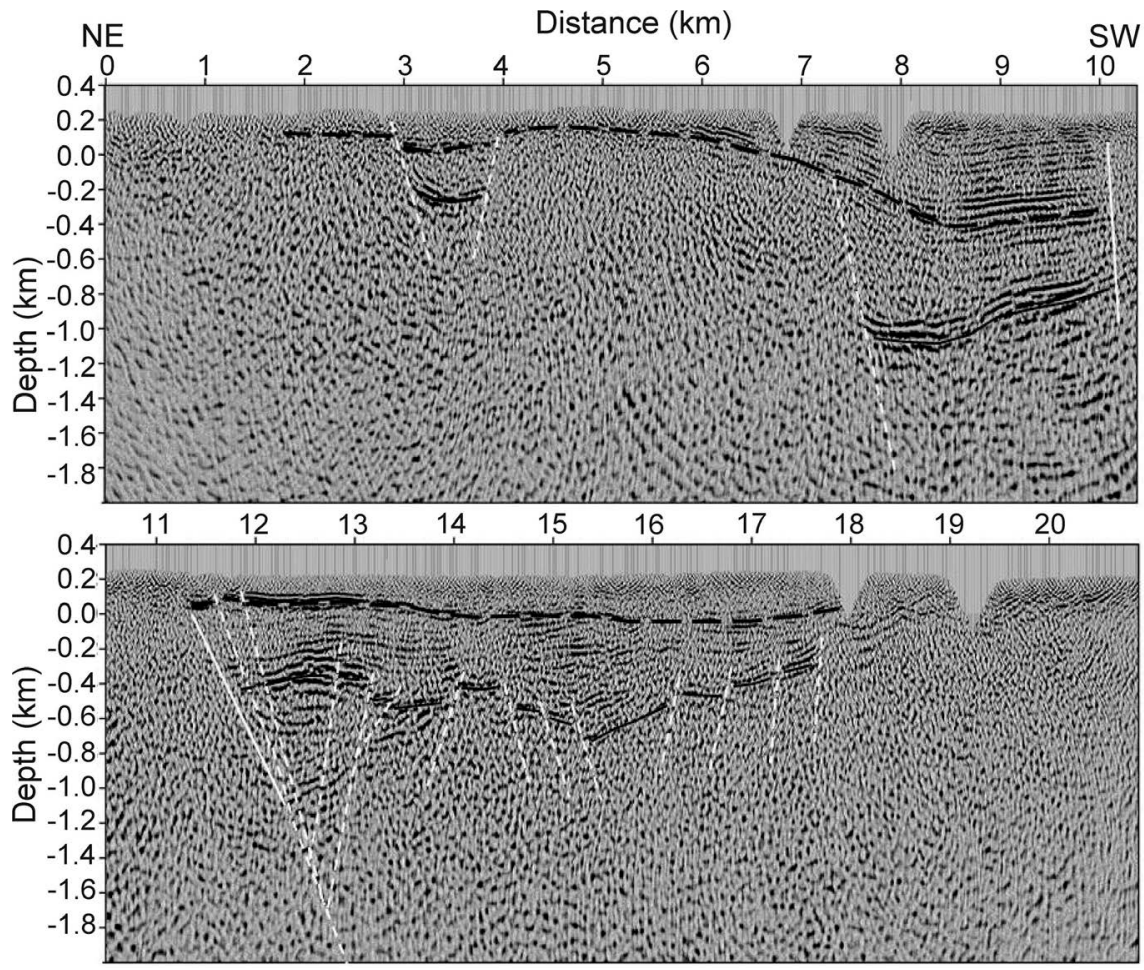

(b)

Figure 14. (a) Uninterpreted depth-converted migrated seismic section obtained for the line P5; (b) Interpreted depth-converted migrated seismic section obtained for the line P5; dashed white lines-Middle Miocene faults, solid white line-edges of intrusive body, dashed black line-interface between seismic sequences, solid black line-top of the basement. 
and, sometimes, high amount of acquisition noise generated during the seismic measurements. I obtained five depth-converted migrated seismic sections after data processing. Four of them provided useful information for the structural interpretation of the subsurface geology. On these seismic sections, I interpreted sequences with undeformed reflectors and inclined reflectors with onlap, toplap and truncation terminations on erosional surfaces. Most of the imaged old sedimentary layers are folded and/or faulted during varies stages from the tectonic evolution of the investigated area. I interpreted intrusive bodies piercing through the sedimentary layers, their location being in good agreement with results from older geophysical studies.

\section{Conflicts of Interest}

The author declares no conflicts of interest regarding the publication of this paper.

\section{References}

[1] Yilmaz, O. (1987) Seismic Data Processing. Society of Exploration Geophysicists.

[2] Rabagia, A. (2009) Sequence Stratigraphy Study of the Northern Part of the Pannonian Basin Performed to Establish Its Tectonic and Stratigraphic Evolution. Ph.D. Dissertation, University of Bucharest, Bucharest. (In Romanian)

[3] Dinu, C., Calota, C., Mocanu, V. and Ciulavu, D. (1991) Geotectonic Setting and the Particular Structural Features of the Besius Basin, on the Basis of Geological and Geophysical Data Synthesis. Revue Roumaine de Geophysique, 35, 77-87.

[4] Sandulescu, M. (1988) Cenozoic Tectonic History of the Carpathians. In: Royden, L.H. and Horváth, F., Eds., The Pannonian Basin: A Study in Basin Evolution, Am. Assoc. Pet. Geol. Memoir, 45, 17-25.

[5] Csontos, L., Nagymarosy, A., Horvath, F. and Kovac, M. (1992) Tertiary Tectonic Evolution of the Intra Carpathian Area a Model. Tectonophysics, 208, 221-241. https://doi.org/10.1016/0040-1951(92)90346-8

[6] Seghedi, I. (2004) Geological Evolution of the Apuseni Mountains with Emphasis on the Neogene Magmatism-A Review. In: Cook, N.J. and Ciobanu, C.L., Eds., Au-Ag-Telluride Deposits of the Golden Quadrilateral, Apuseni Mts., Romania: Guidebook of the International Field Workshop of IGCP Project 486, Romania, 5-23.

[7] Royden, L.H. (1988) Late Cenozoic Tectonics of the Pannonian Basin System. In: Royden, L.H. and Horváth, F., Eds., The Pannonian Basin: A Study in Basin Evolution, Am. Assoc. Pet. Geol. Memoir, 45, 27-48. 